\title{
MAP OF PLACES MENTIONED
}

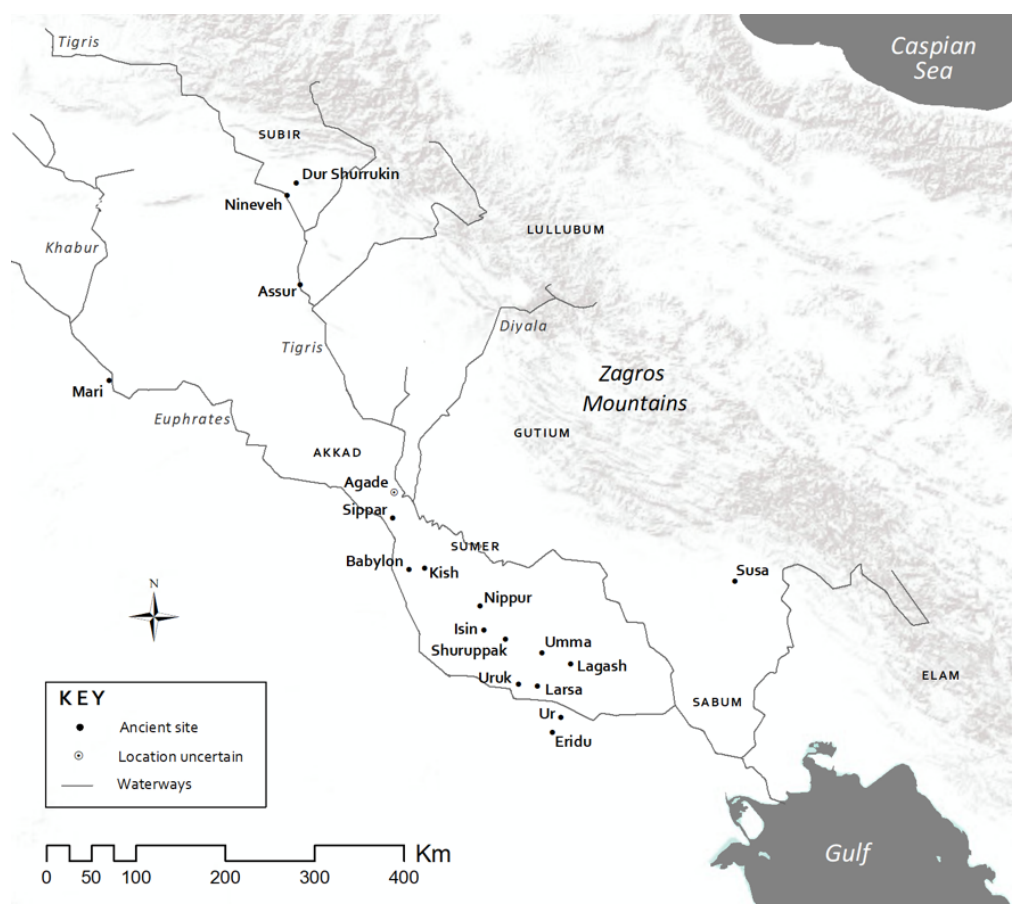


